Review

\title{
Angiotensin-Converting-Enzyme 2 and SARS-CoV2: A Dangerous Liaison
}

\author{
Adrian Sturza ${ }^{1,2}$, Cătălin V. Marian ${ }^{3}$, Danina M. Muntean ${ }^{1,2, *}$ and Octavian M. Crețu ${ }^{4}$ \\ ${ }^{\text {I }}$ Department of Functional Sciences-Pathophysiology, Faculty of Medicine, "Victor Babeș” University of Medicine \\ and Pharmacy, Eftimie Murgu Sq. no. 2, 30004I Timişoara, Romania; sturza.adrian@umft.ro \\ ${ }^{2}$ Center for Translational Research and Systems Medicine, Faculty of Medicine, "Victor Babeș” University of \\ Medicine and Pharmacy, Eftimie Murgu Sq. no. 2, 30004I Timişoara, Romania \\ 3 Department of Biochemistry, Faculty of Medicine, "Victor Babeș” University of Medicine and Pharmacy, \\ Eftimie Murgu Sq. no. 2, 30004I Timișoara, Romania; cmarian@umft.ro \\ ${ }^{4}$ Department of Surgery I, Faculty of Medicine, "Victor Babeș” University of Medicine and Pharmacy, \\ Eftimie Murgu Sq. no. 2, 30004I Timişoara, Romania; octavian.cretu@umft.ro \\ *Correspondence: daninamuntean@umft.ro
}

Submitted: 2I September 2020; Accepted: 20 October 2020; Published: 26 October 2020

\begin{abstract}
The renin-angiotensin-aldosterone system (RAAS) has been recognized as a key player in the complex scenario of cardiovascular regulation. Aside from its role in the cardiovascular diseases, RAAS dysregulation has emerged as a central pathomechanism in the severe acute respiratory syndrome coronavirus I (SARS-CoVI) epidemic, dating back to 2002-2004, and the current COVID-I9 pandemic with SARS-CoV2, with the latter involving the interaction with angiotensin-converting enzyme 2 (ACE2). $\mathrm{ACE}_{2}$ is the enzyme responsible for Ang I-7 production that partly counteracts the RAAS effects and promotes nitric oxide synthase activation; moreover, it has also been reported to act as a receptor for both SARS viruses. In the setting of the ongoing COVID-19 pandemic, the SARS-ACE2 interaction is highly debated with respect to both viral infectivity and usage/discontinuation of RAAS medication-ACE inhibitors (ACEi) and angiotensin-receptor blockers (ARBs) - in diagnosed or suspected SARS-CoV2 patients. Since ACE inhibitors and ARBs are largely prescribed in cardiovascular pathology, a better understanding of the interaction between SARS-CoV2 and RAAS is urgently needed. In this review, we will briefly discuss the SARS-CoV2 and $\mathrm{ACE}_{2}$ interaction and why the discontinuation of RAAS medication is unsafe for either diagnosed or suspected SARS-CoV2 patients.
\end{abstract}

Keywords: angiotensin-converting-enzyme 2; SARS-Cov2; COVID-I9 pandemic

How to cite: Sturza, A.; Marian, C.V.; Muntean, D.M.; Cretu, O.M. Angiotensin-Converting-Enzyme 2 and SARS-CoV2: A Dangerous Liaison. Timisoara Med. 2020, 2020(I), 8; doi:I0.35995/tmj20200108.

\section{Introduction}

The world continues to face the challenge of the COVID-I9 pandemic, caused by the SARS-CoV2 virus, which is responsible for acute lung injury and its major complication, acute respiratory distress syndrome (ARDS), respectively [ $\mathrm{I}]$. This pathogen interferes with the renin-angiotensin-aldosterone system (RAAS) activity and, more precisely, has a high affinity for angiotensin-converting enzyme 2 (ACE2), an enzyme 
that is mainly responsible for the conversion of angiotensin II (ATII) into angiotensin I-7 [2]. During RAAS activation, AT II binds to angiotensin II type I receptors (ATIR) with several deleterious effects in the long run, such as increased blood pressure, vasoconstriction, fluid retention, chronic inflammation, and cardiovascular remodeling [3]. The ACE2 protein can be found in two forms, membrane $\mathrm{ACE}_{2}\left(\mathrm{mACE}_{2}\right)$ and soluble (sACE2). mACE2 is expressed on the surface of lung alveolar epithelial cells, enterocytes, cardiomyocytes, and endothelial cells from virtually all organs [4-6] that elicit opposite, anti-inflammatory, vasodilatory effects and a decrease in blood pressure via Ang I-7 generation $[7,8]$. An interaction between SARS-Cov2 and $\mathrm{mACE}_{2}$ followed by virus replication will "block" the action of the enzyme through the shedding of ACE2 by means of the A Disintegrin and Metalloprotease (ADAM) I7 protease (ADAM-A Disintegrin and Metalloprotease), thus reducing the expression of the former [9]; the same effect was initially reported for SARS-CoVI $[\mathrm{Io}]$. Important, sACE2 will remain active, not being influenced by the shedding process. As a consequence of lower ACE2 activity/expression, excessive ATII levels will promote lung injury, myocarditis, thrombotic events, and the damage of kidneys and the digestive system. It was reported in a small group of I2 patients with pneumonia and infected with SARS-CoV2 that plasma ATII level was significantly increased and correlated with both lung injuries and viral load [II].

In early studies about fatality rates in SARS-CoV2 infection, a high prevalence of comorbidities such as hypertension, cardiovascular disease, diabetes, malignancies and chronic pulmonary disease was reported [I2-I4]. Notably, patients with chronic obstructive pulmonary disease had a fourfold higher risk of developing COVID-I9 [I5]. Moreover, elderly patients had an increased susceptibility for this infection, as has been recently shown [I4].

Since most patients with cardiovascular and metabolic diseases are treated with ARBs or ACEi, a major concern was raised about the safety and/or persistent beneficial effects of these drugs in SARS-CoV2-infected patients. It was suggested that the interaction between SARS-CoV2 and $\mathrm{ACE}_{2}$ is an important factor for disease aggravation $[16,17]$. Currently, there are several ongoing clinical trials that investigate the effects of ACEi and ARBs usage in the setting of SARS-CoV2 infection (Table I). A couple of these studies already concluded that ARBs and ACEi do not aggravate morbidity and mortality in COVID-19 patients with cardiovascular diseases [18] and strongly recommended treatment continuation if indicated [19].

A better understanding of the interaction between SARS-CoV2 and RAAS components is needed for the appropriate therapeutic management of these patients.

\section{ACE2 and RAAS Interaction}

ACE2 is a transmembrane glycoprotein (mono-carboxypeptidase), a homolog of ACE (40\% identic) [8,I4], which converts ATII into its protective metabolite, Ang I-7. Furthermore, ACE2 can convert angiotensin I into Ang I-9, which will be further transformed by ACE and ACE2 into Ang I-7 [8,20]. By all these effects, $\mathrm{ACE} 2$ can suppress the activity of RAAS and reduce vasoconstriction and cardiovascular remodeling [2I].

Normally, ATIR and ACE2 interact and form complexes on the cellular surface [22]. High levels of ATII will separate and release $\mathrm{ACE}_{2}$ (shedding), a process activated by the metalloproteinase $\mathrm{ADAM}_{7}$ (upregulated by ATII) $[9,22]$. Even though the process of shedding represents an important mechanism of ACE2 regulation, the amount of the soluble form of $\mathrm{ACE}_{2}$ is small [23]. Interestingly, it was reported that SARS-CoV2 can be blocked by the recombinant soluble ACE2 [24], which might represent a therapeutic option for SARS-CoV2 as well; in this respect, a pilot trial (NCTo4335136) has been launched (Table I). ACE2 represents an important regulatory enzyme of RAAS not only by the reduction in ATII levels, but also because its product-Ang I-7-has specific effects by acting on the recently discovered receptor Mas (Mas oncogene 
product) $[6,7]$. The interaction with this receptor will block ATIR and activate nitric oxide synthase (NOS) with NO production and the suppression of ATII effects [25]. Importantly, Ang I-7 is able to have a crosstalk interaction with the angiotensin type 2 receptor $\left(A T_{2} R\right)$ and bradykinin type 2 receptor $\left(B K_{2} R\right)[3,26]$. Alterations in the Ang I-7 levels are associated with hypertension, myocardial hypertrophy, myocardial infarction, liver disease and chronic kidney disease [27].

The crucial role of ACE2 in cardiac regulation was firstly described in experimental models. Accordingly, ACE2 deficiency in rodents leads to increased levels of ATII, oxidative stress, inflammation, and hypertension through ATIR activation. ACE2 knockout mice developed increased local cardiac ATII, high oxidative stress, neutrophilic infiltration and pathological hypertrophy [28]. An elevated activity and ACE2 gene expression in pericytes (as compensatory mechanisms) were reported in patients with heart failure and were correlated with severity of the disease [29].

In addition, $\mathrm{ARB}$ and $\mathrm{ACEi}$ were able to increase $\mathrm{ACE} 2$ activity and mRNA gene expression in the rat heart. To date, no data about such an increase at the tissue level were reported in humans; however, ongoing studies are investigating the effects of RAAS medication on circulating ACE2 levels.

The dual effect of RAAS activation is depicted in Figure I.

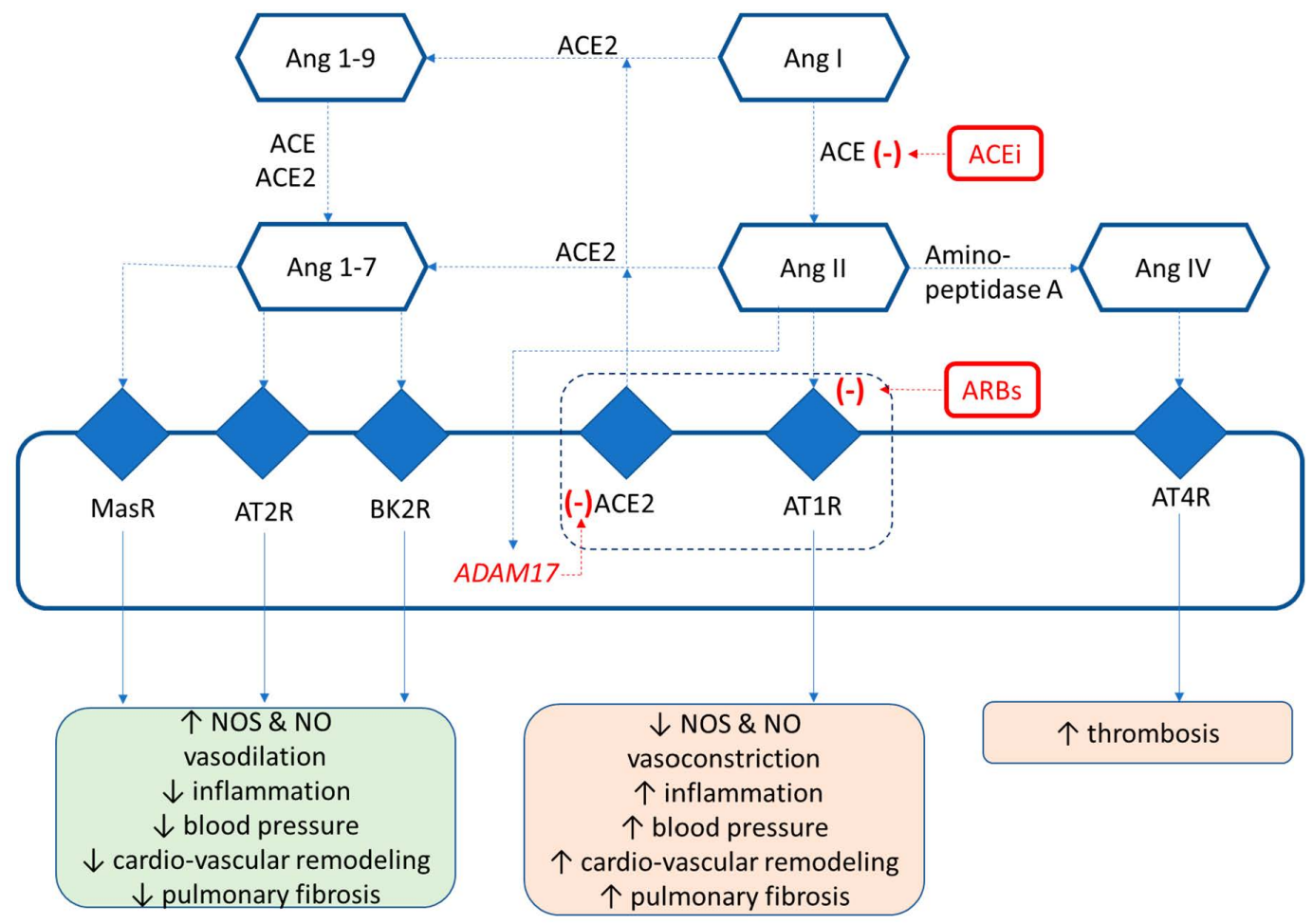

Figure 1. Renin-angiotensin-aldosterone system (RAAS) components-the balance between angiotensin-converting enzyme (ACE) and ACE2 effects. Ang I = angiotensin I, Ang II = angiotensin II, Ang I-7 = angiotensin I-7 peptide, Ang I-9 = angiotensin I-9 peptide, $\mathrm{ACE}=$ angiotensin I converting enzyme $\mathrm{I}, \mathrm{ACE} 2=$ angiotensin I converting enzyme 2, $\mathrm{AT}_{\mathrm{I}} \mathrm{R}=$ angiotensin II receptor type $\mathrm{I}, \mathrm{AT} \mathrm{T}_{2} \mathrm{R}=$ angiotensin II receptor type $2, \mathrm{AT}_{4} \mathrm{R}=$ angiotensin II receptor type 4 , MasR = Mas oncogene (a G-protein-coupled receptor), $\mathrm{BK} 2 \mathrm{R}=$ bradykinin type 2 receptor, $\mathrm{NO}=$ nitric oxide, NOS $=$ nitric oxide synthase. 


\section{SARS-CoV2-ACE2 Interaction}

SARS-CoV2 is a pathogen which shares many similarities with SARS-CoVI, including $76 \%$ of spike (S) protein sequence identity [30] and an increased affinity for ACE2 ( $10-20-$ fold higher than that of SARS-CoVI) [3I].

In the heart and lungs, binding of $\mathrm{SARS}_{-} \mathrm{CoV}_{2}$ to $\mathrm{ACE}_{2}$ (which acts as a functional receptor) will lead to ACE2 internalization $[4,6]$. After the binding and endocytosis of SARS-CoV2, ACE2 expression will decrease, with a subsequent increase in ATII accumulation. Importantly, ACE2 expression can be directly reduced by viral replication [32] or through the activation of $\mathrm{ADAM}_{17}$, the enzyme responsible for $\mathrm{ACE}_{2}$ shedding and inactivation (Figure 2).

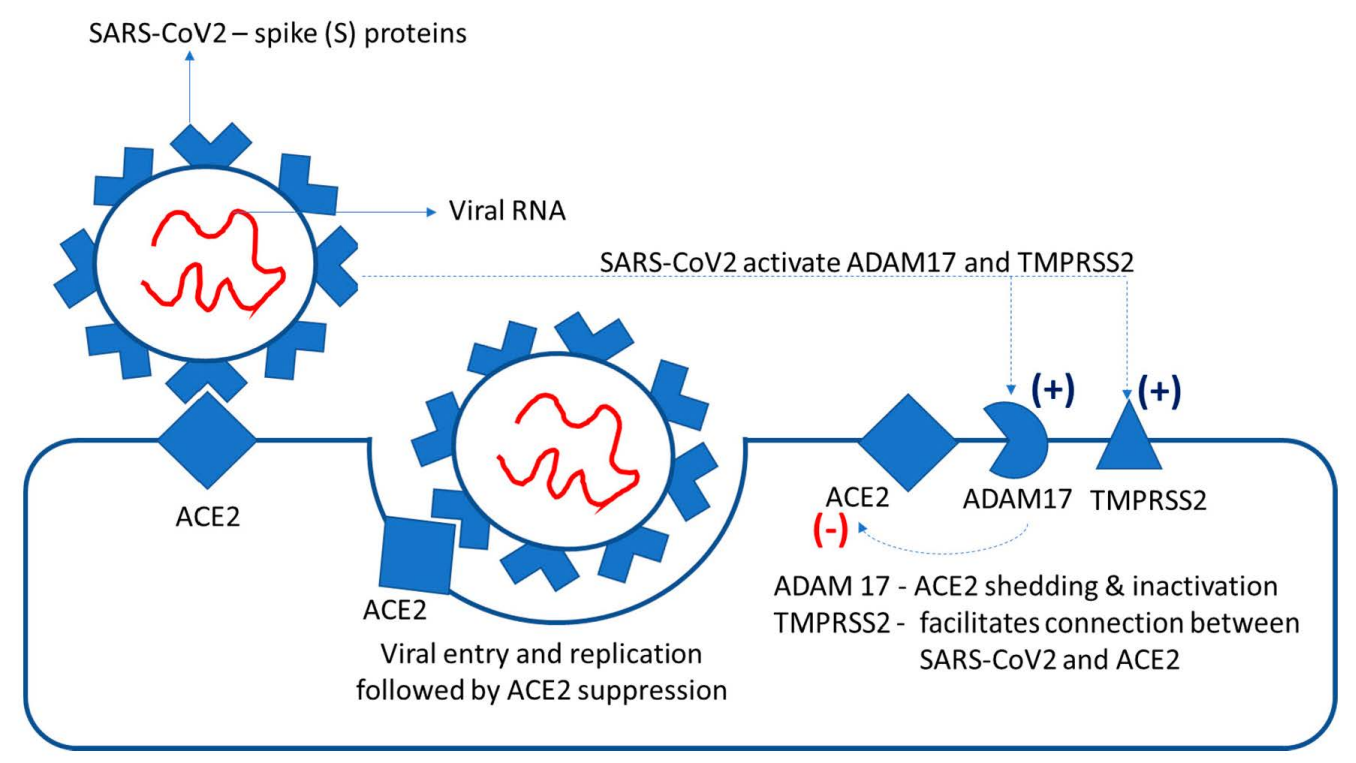

Figure 2. Mechanisms of SARS- $\mathrm{CoV}_{2}-\mathrm{ACE}_{2}$ binding and inactivation.

The "liaison" between SARS-CoV2 and ACE2 receptors is mediated by the spike (S) viral glycoprotein from the viral envelope that is also responsible for the "corona"-like appearance of the virus (Figure 2). The binding process is facilitated by transmembrane protease serine 2 (TMPRSS 2 ), a membrane protease important for the connection between SARS-CoV2 and $\mathrm{ACE}_{2}$ with subsequent viral entry inside the cells (Figure 2) [33].

Genetic susceptibility can be responsible for the rapid spreading of SARS-CoV2. More specifically, it was observed that $\mathrm{ACE}_{2}$ polymorphism (p.Arg5I4Gly in the African/African-American population) is associated with pulmonary and cardiovascular states, and TMPRSS2 polymorphism (p.Valı6oMet_rsi2329760) can be responsible for the genetic susceptibility to SARS- $\mathrm{CoV}_{2}$ infection (including risk factors such as cancer and male patients) [34].

ACE2 represents the "entry door" for both SARS-CoVI and SARS-COv2. Indeed, in an experimental model of SARS-CoVI infection in mice, viral entry facilitated the increased expression of ACE2 [35]. Conversely, in ACE2 knockout mice, the burden of infection with SARS-CoVI was significantly reduced [4].

On the other hand, ACE2 exerts beneficial effects via the degradation of ATII into Ang I-7. Suppression of activity/expression of ACE2 will lead to high ATII levels with lung and cardiovascular consequences, 
an observation reported in a group of patients with SARS-CoV2 infection where plasma levels of ATII were correlated with both the viral load and these types of injuries [II]. Notably, correlations of ATII levels with the viral load and disease severity were also reported in other conditions such as influenza $\mathrm{H}_{5} \mathrm{~N}_{7}$ and respiratory syncytial viral infections $[36,37]$.

\section{SARS-CoV2 Infection, ACE2 and ACEi/ARB Treatment}

Several studies reported that RAAS medication (ACEi and ARB) can increase the membrane ACE2 expression in the cardiovascular system $[38,39]$. Since ACE2 is the receptor that facilitates SARS-CoV2 entry, treatment with these drugs in patients with hypertension and heart failure was suspected to elicit harmful effects in the setting of SARS-CoV2 infection [17]. However, this hypothesis was not confirmed, since the beneficial effects of ARB via the blockade of ATII action on ATIR appear to prevail [40].

The current hypotheses regarding the dual effect of RAAS inhibition in the presence of SARS-CoV 2 infection are depicted in Figure 3.

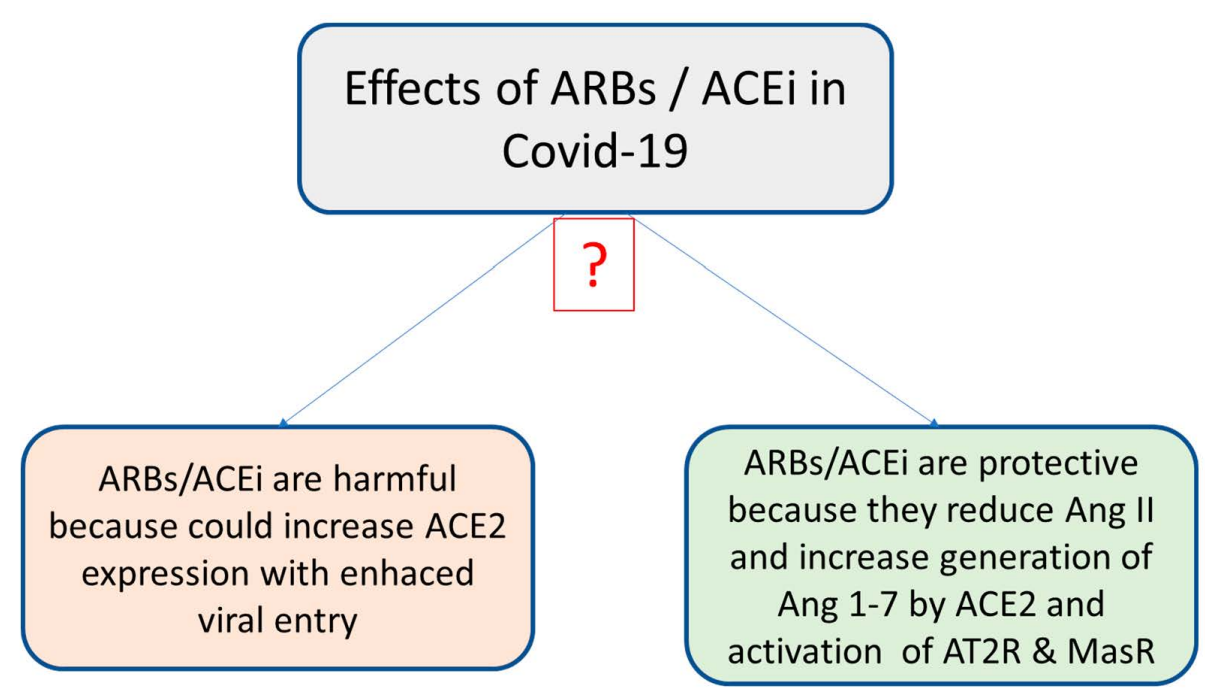

Figure 3. Current hypotheses regarding the effects of angiotensin-receptor blockers (ARBs) and ACE inhibitors (ACEi) in COVID-I9 patients.

It has been previously reported in the literature that the SARS-CoV2 infection is more severe in patients with cardiovascular diseases (hypertension, myocardial injury, cardiomyopathy) [4I,42], conditions where RAAS medication provides indubitable protection. Thus, discontinuation of these drugs could increase the propensity for decompensation in high-risk patients. When considering the opposite effects on ACE2, i.e., upregulation of $\mathrm{ACE}_{2}$ (induced by $\mathrm{ARB}$ and $\mathrm{ACEi}$ ) vs. downregulation of $\mathrm{ACE}_{2}$ (induced by SARS-CoV2), it is most probably more advantageous to have higher rather than lower enzymatic levels; thus, more ACE2 will be available to limit the ATII effects. In animal studies, ARBs and ACEi showed clearly beneficial effects [4] and a decrease in ACE2 was already reported to be responsible for the maladaptive ventricular remodeling after myocardial infarction [43].

Importantly, no data are currently available in the literature to support the hypothesis that ACEi or ARBs increase the infection rates and/or the severity of the lesions in COVID-19 patients. Therefore, these drugs represent important therapeutic options, if indicated, in the presence of $\mathrm{SARS}_{-} \mathrm{CoV}_{2}$ infection. There are 
animal studies that clearly present the beneficial effects of ARBs on lung injury in SARS-CoV2-infected mice [4].

There are both ongoing and finalized clinical trials (Table I) that address the effects of RAAS medication in COVID-I9 patients, in addition to vaccines and antiviral drugs. Accordingly, the Valsartan for Prevention of Acute Respiratory Distress Syndrome in Hospitalized Patients With SARS-CoV2 (COVID-I9) Infection Disease (PRAETORIAN-COVID) trial (NCTo4335786, Table I) investigates the effect of valsartan in SARS-CoV2-infected patients [44]. Other trials investigate the effects of losartan in COVID-I9 patients requiring or not requiring hospitalization (NCTo4312009, NCTo431II77, Table I). The Angiotensin Receptor Blockers and Angiotensin-Converting Enzyme Inhibitors and Adverse Outcomes in Patients With COVIDis (BRACE-CORONA) trial showed that interruption of ACEi/ARBs for 30 days is not beneficial for COVID-I9 patients and the recommendation is to continue the treatment for those with therapeutic indication [19].

Table 1. Clinical trials for investigation of treatment with ARBs and ACEi in COVID-r9 patients (source: ClinicalTrials.gov).

\begin{tabular}{|c|c|}
\hline Trial Number & Title \\
\hline NCTo4312009 & Losartan for Patients with COVID-ı9 Requiring Hospitalization \\
\hline NCTo43III77 & Losartan for Patients with COVID-ı9 Not Requiring Hospitalization \\
\hline NCTo4335136 & $\begin{array}{l}\text { Recombinant Human Angiotensin-converting Enzyme } 2 \text { (rhACE2) as a Treatment for Patients with } \\
\text { COVID-r9 (APNoI-COVID-19) }\end{array}$ \\
\hline NCTo4364893 & $\begin{array}{l}\text { Angiotensin Receptor Blockers and Angiotensin-Converting Enzyme Inhibitors and Adverse Outcomes in } \\
\text { Patients with COVIDı9 (BRACE-CORONA) }\end{array}$ \\
\hline NCTo4338009 & $\begin{array}{l}\text { Elimination or Prolongation of ACE Inhibitors and ARB in Coronavirus Disease } 2019 \\
\text { (REPLACECOVID) }\end{array}$ \\
\hline NCTo4375046 & $\begin{array}{l}\text { Recombinant Bacterial ACE2 Receptors - Like Enzyme of B38-CAP Could be Promising COVID-I9 } \\
\text { Infection—and Lung Injury Preventing Drug Better Than Recombinant Human ACE2 (Bacterial ACE2) }\end{array}$ \\
\hline NCTo4318418 & ACE Inhibitors, Angiotensin II Type-I Receptor Blockers and Severity of COVID-I9 (CODIV-ACE) \\
\hline NCTo4353596 & Stopping ACE inhibitors in COVID-I9 (ACEI-COVID) \\
\hline NCTo4357535 & Prognosis of Coronavirus Disease 2019 (COVID-19) Patients Receiving Antihypertensives \\
\hline NCTo4364893 & $\begin{array}{l}\text { Angiotensin Receptor Blockers and Angiotensin-Converting Enzyme Inhibitors and Adverse Outcomes in } \\
\text { Patients with COVIDi9 (BRACE-CORONA) }\end{array}$ \\
\hline NCTo4337190 & Impact of Angiotensin II Receptor Blockers Treatment in Patients with COVID I9 (COVID-ARA2) \\
\hline NCTo4367883 & Influenza Vaccination, ACEI and ARB in the Evolution of SARS-COVIDig Infection \\
\hline NCTo4329195 & ACE Inhibitors or ARBs Discontinuation in Context of SARS-CoV2 Pandemic \\
\hline NCTo4519398 & $\begin{array}{l}\text { Investigating the Involvement of ACE and Angiotensinogen Genes' Polymorphism Along with Other } \\
\text { Thrombophilic Genotypes in Severe Forms of COVID-19 with/without Thrombotic Events }\end{array}$ \\
\hline NCTo4338009 & Elimination or Prolongation of ACE Inhibitors and ARB in Coronavirus Disease 2019 \\
\hline NCTo4351581 & Effects of Discontinuing Renin-Angiotensin System Inhibitors in Patients with COVID-I9 \\
\hline NCTo4331574 & Renin-Angiotensin System Inhibitors and COVID-I9 \\
\hline NCTo4394II7 & Controlled Evaluation of Angiotensin Receptor Blockers for COVID-ı9 Respiratory Disease (CLARITY) \\
\hline NCTo4355936 & Telmisartan for Treatment of COVID-19 Patients \\
\hline NCTo4335786 & $\begin{array}{l}\text { Valsartan for Prevention of Acute Respiratory Distress Syndrome in Hospitalized Patients with } \\
\text { SARS-CoV2 (COVID-I9) Infection Disease (PRAETORIAN-COVID) }\end{array}$ \\
\hline
\end{tabular}




\section{Novel Therapeutic Strategies: Recombinant ACE2 and Regulation of Protease Activity}

Severe cases of SARS-CoV2 infection are more common in men than in women and in adults/the elderly than in children [45]. Furthermore, the death rate is sex-dependent, being significantly higher in men compared to women [46]. The underlying mechanisms have not been elucidated so far, but, among the contributing factors, smoking, impaired immune response, and the regulation of TMPRSS 2 and ADAMr7 have been incriminated $[9,47]$. Moreover, differences in $\mathrm{mACE} 2$ expression associated with high AngII levels, ADAMi7 activity and increased mACE2 shedding were reported [48], particularly in males [49]. Additionally, it was observed that high levels of sACE2 represent a higher risk factor for severe COVID-I9 in adults $>$ children and in men $>$ women [48,50]. In this respect, in two groups of COVID-I9 patients with heart failure, $\mathrm{sACE}_{2}$ was found to be higher in men vs. women, an observation that might explain the increased rate of death in men [50].

Regarding SARS-CoV2 treatment, an interesting therapeutic possibility is represented by recombinant $\mathrm{ACE}_{2}$ (Figure 4). The beneficial effects of recombinant $\mathrm{ACE}_{2}$ were demonstrated in animal models of acute lung failure [5I]. In this respect, a clinical trial that uses circulating soluble recombinant $\mathrm{ACE}_{2}$ to bind SARS-CoV 2 and to prevent its connection with membrane-bound ACE2 is ongoing (NCTo4335136, Table I).

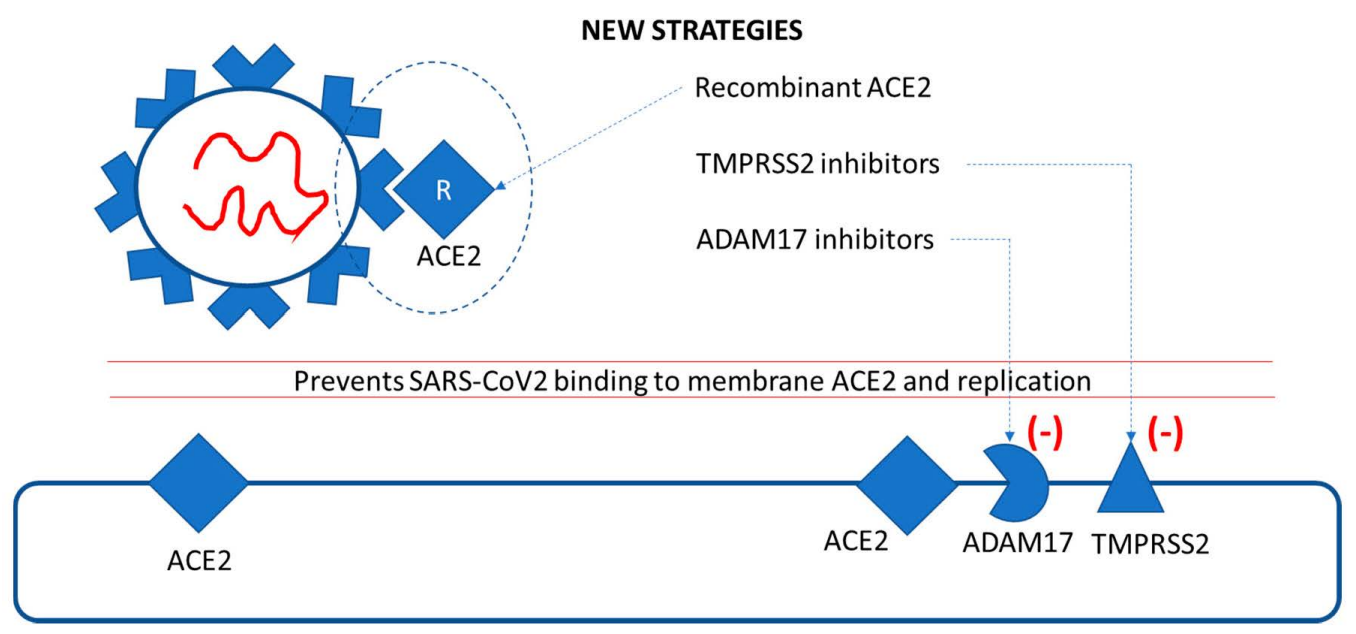

Figure 4. New therapeutic strategies for preventing SARS-CoV2-ACE2 binding and replication: recombinant $\mathrm{ACE}_{2}$ and inhibitors of proteases A Disintegrin and Metalloprotease (ADAM)I7 and transmembrane protease serine 2 (TMPRSS 2 ).

As mentioned before, the process of binding SARS-CoV2 to $\mathrm{ACE}_{2}$ is regulated by two membrane proteases, $\mathrm{ADAM}_{17}$ and TMPRSS2. Their inhibition currently represents the newest therapeutic approach (Figure 4). TMPRSS 2 has a crucial role in SARS- $\mathrm{CoV}_{2}$ infection (and also in influenza $\mathrm{A}$ virus infection); interestingly, the protease has been reported to be upregulated by androgen hormones, e.g., in prostate cancer [52]. A Japanese trial that investigates the efficiency of two TMPRSS 2 inhibitors (nafamostat and camostat) in the treatment of COVID-I9 infection is ongoing [53,54].

\section{Conclusions}

ACE2, the enzyme responsible for the conversion of ATII into Ang $\mathrm{I}-7$, also acts as a receptor for SARS-CoV2, the currently ongoing and pandemic-causing coronavirus. ACE2 expression is increased in response to ACEi and ARBs, and there have been concerns regarding their usage in SARS-CoV2 patients. Several clinical trials 
are ongoing to test the safety and beneficial effects of RAAS medication (ACEi, ARBs) as well as new classes of drugs (recombinant human ACE2 and inhibitors of proteases ADAMr7 and TMPRSS2). Until new data are available, the continuation of RAAS medication is recommended in patients suspected or confirmed to have SARS-CoV2 infection.

Author Contributions: Conceptualization, A.S., D.M.M, C.V.M. and O.M.C.; writing-original draft preparation, A.S., D.M.M., C.V.M. and O.M.C.; writing-review and editing, A.S., D.M.M., C.V.M. and O.M.C.; supervision, D.M.M. and O.M.C.

Funding: This research received no external funding.

Conflicts of Interest: The authors declare no conflicts of interest.

\section{References}

I. Guan, W.-J.; Ni, Z.-Y.; Hu, Y.; Liang, W.-H.; Ou, C.-Q.; He, J.-X.; Liu, L.; Shan, H.; Lei, C.-L.; Hui, D.S.C.; et al. Clinical Characteristics of Coronavirus Disease 2019 in China. N. Engl. J. Med. 2020, 382, 1708-1720. [CrossRef] [PubMed]

2. Li, W.; Moore, M.J.; Vasilieva, N.; Sui, J.; Wong, S.K.; Berne, M.A.; Somasundaran, M.; Sullivan, J.L.; Luzuriaga, K.; Greenough, T.C.; et al. Angiotensin-converting enzyme 2 is a functional receptor for the SARS coronavirus. Nat. Cell Biol. 2003, 426, 450-454. [CrossRef] [PubMed]

3. Nehme, A.; Zouein, F.A.; Zayeri, Z.D.; Zibara, K. An Update on the Tissue Renin Angiotensin System and Its Role in Physiology and Pathology. J. Cardiovasc. Dev. Dis. 2019, 6, 14. [CrossRef] [PubMed]

4. Kuba, K.; Imai, Y.; Rao, S.; Gao, H.; Guo, F.; Guan, B.; Huan, Y.; Yang, P.; Zhang, Y.; Deng, W.; et al. A crucial role of angiotensin converting enzyme 2 (ACE2) in SARS coronavirus-induced lung injury. Nat. Med. 2005, 11, 875-879. [CrossRef] [PubMed]

5. Oudit, G.Y.; Kassiri, Z.; Jiang, C.; Liu, P.P.; Poutanen, S.M.; Penninger, J.M.; Butany, J. SARS-coronavirus modulation of myocardial ACE2 expression and inflammation in patients with SARS. Eur. J. Clin. Investig. 2009, 39, 618-625. [CrossRef]

6. Zores, F.; Rebeaud, M.E. COVID and the Renin-Angiotensin System: Are Hypertension or Its Treatments Deleterious? Front. Cardiovasc. Med. 2020, 7, 71. [CrossRef]

7. Hamming, I.; Cooper, M.E.; Haagmans, B.L.; Hooper, N.M.; Korstanje, R.; Osterhaus, A.D.M.E.; Timens, W.; Turner, A.J.; Navis, G.; Van Goor, H. The emerging role of ACE2 in physiology and disease. J. Pathol. 2007, 212, I-II. [CrossRef]

8. Donoghue, M.; Hsieh, F.; Baronas, E.; Godbout, K.; Gosselin, M.; Stagliano, N.; Donovan, M.; Woolf, B.; Robison, K.; Jeyaseelan, R.; et al. A Novel Angiotensin-Converting Enzyme-Related Carboxypeptidase (ACE2) Converts Angiotensin I to Angiotensin I-9. Circ. Res. 2000, 87, EI-E9. [CrossRef]

9. Palau, V.; Riera, M.; Soler, M.J. ADAMry inhibition may exert a protective effect on COVID-r9. Nephrol. Dial. Transplant. 2020, 35, I07I-IO72. [CrossRef] [PubMed]

Io. Lambert, D.W.; A Yarski, M.; Warner, F.J.; Thornhill, P.; Parkin, E.T.; Smith, A.I.; Hooper, N.M.; Turner, A.J. Tumor Necrosis Factor- $\alpha$ Convertase (ADAMr7) Mediates Regulated Ectodomain Shedding of the Severe-acute Respiratory Syndrome-Coronavirus (SARS-CoV) Receptor, Angiotensin-converting Enzyme-2 (ACE2).J. Biol. Chem. 2005, 280, 30113-30119. [CrossRef]

II. Liu, Y.; Yang, Y.; Zhang, C.; Huang, F.; Wang, F.; Yuan, J.; Wang, Z.; Li, J.; Li, J.; Feng, C.; et al. Clinical and biochemical indexes from $2019-\mathrm{nCoV}$ infected patients linked to viral loads and lung injury. Sci. China Life Sci. 2020, 63, 364-374. [CrossRef]

I2. Sanyaolu, A.; Okorie, C.; Marinkovic, A.; Patidar, R.; Younis, K.; Desai, P.; Hosein, Z.; Padda, I.; Mangat, J.; Altaf, M. Comorbidity and its Impact on Patients with COVID-19. SN Compr. Clin. Med. 2020, 2, 1069-1076. [CrossRef]

13. Singh, A.K.; Gupta, R.; Ghosh, A.; Misra, A. Diabetes in COVID-19: Prevalence, pathophysiology, prognosis and practical considerations. Diabetes Metab. Syndr. Clin. Res. Rev. 2020, 14, 303-310. [CrossRef]

I4. Liu, K.; Chen, Y.; Lin, R.; Han, K. Clinical features of COVID-ig in elderly patients: A comparison with young and middle-aged patients. J. Infect. 2020, 80, eı4-er8. [CrossRef]

I5. Zhao, Q.; Meng, M.; Kumar, R.; Wu, Y.; Huang, J.; Lian, N.; Deng, Y.; Lin, S. The impact of COPD and smoking history on the severity of COVID-19: A systemic review and meta-analysis. J. Med. Virol. 2020, 92, 1915-1921. [CrossRef]

16. Esler, M.; Esler, D. Can angiotensin receptor-blocking drugs perhaps be harmful in the COVID-19 pandemic? J. Hypertens. 2020, 38, 781-782. [CrossRef]

17. Watkins, J. Preventing a covid-I9 pandemic. BMJ 2020, 368, m8ı. [CrossRef] 
I8. Peng, Y.D.; Meng, K.; Guan, H.Q.; Leng, L.; Zhu, R.R.; Wang, B.Y.; A He, M.; Cheng, L.X.; Huang, K.; Zeng, Q.T. [Clinical characteristics and outcomes of II2 cardiovascular disease patients infected by $2019-\mathrm{nCoV}$ ]. Zhonghua Xin Xue Guan Bing Za Zhi 2020, 48, Eoo4.

19. Lopes, R.D.; Macedo, A.V.S.; Silva, P.G.M.D.B.E.; Moll-Bernardes, R.J.; Feldman, A.; Arruda, G.D.S.; De Souza, A.S.; De Albuquerque, D.C.; Mazza, L.; Santos, M.F.; et al. Continuing versus suspending angiotensin-converting enzyme inhibitors and angiotensin receptor blockers: Impact on adverse outcomes in hospitalized patients with severe acute respiratory syndrome coronavirus 2 (SARS-CoV-2) - The BRACE CORONA Trial. Am. Heart J. 2020, 226, 49-59. [CrossRef]

2o. Ferrario, C.M.; Jessup, J.; Gallagher, P.E.; Averill, D.B.; Brosnihan, K.B.; Tallant, E.A.; Smith, R.D.; Chappell, M.C. Effects of renin-angiotensin system blockade on renal angiotensin-(I-7) forming enzymes and receptors. Kidney Int. 2005, 68, 2189-2196. [CrossRef]

2I. Tikellis, C.; Thomas, M.C. Angiotensin-Converting Enzyme 2 (ACE2) Is a Key Modulator of the Renin Angiotensin System in Health and Disease. Int. J. Pept. 2012, 2012, 256294. [CrossRef] [PubMed]

22. Deshotels, M.R.; Xia, H.; Sriramula, S.; Lazartigues, E.; Filipeanu, C.M. Angiotensin II Mediates Angiotensin Converting Enzyme Type 2 Internalization and Degradation Through an Angiotensin II Type I Receptor-Dependent Mechanism. Hypertension 2014, 64, 1368-1375. [CrossRef] [PubMed]

23. Lambert, D.W.; Hooper, N.M.; Turner, A.J. Angiotensin-converting enzyme 2 and new insights into the renin-angiotensin system. Biochem. Pharmacol. 2008, 75, 78I-786. [CrossRef]

24. Batlle, D.; Wysocki, J.; Satchell, K. Soluble angiotensin-converting enzyme 2: A potential approach for coronavirus infection therapy? Clin. Sci. 2020, 134, 543-545. [CrossRef]

25. Ingelfinger, J.R. Angiotensin-converting enzyme 2: Implications for blood pressure and kidney disease. Curr. Opin. Nephrol. Hypertens. 2009, 18, 79-84. [CrossRef]

26. Tom, B.; Dendorfer, A.; Danser, A.H.J. Bradykinin, angiotensin-(I-7), and ACE inhibitors: How do they interact? Int. J. Biochem. Cell Biol. 2003, 35, 792-8or. [CrossRef]

27. Ribeiro-Oliveira, A., Jr.; Nogueira, A.I.; Pereira, R.M.; Boas, W.W.; Dos Santos, R.A.; Simõoes E Silva, A.C. The renin-angiotensin system and diabetes: An update. Vasc. Health Risk Manag. 2008, 4, 787-803. [CrossRef]

28. Oudit, G.Y.; Kassiri, Z.; Patel, M.P.; Chappell, M.; Butany, J.; Backx, P.H.; Tsushima, R.G.; Scholey, J.W.; Khokha, R.; Penninger, J.M. Angiotensin II-mediated oxidative stress and inflammation mediate the age-dependent cardiomyopathy in ACE2 null mice. Cardiovasc. Res. 2007, 75, 29-39. [CrossRef]

29. Chen, L.; Li, X.; Chen, M.; Feng, Y.; Xiong, C. The ACE2 expression in human heart indicates new potential mechanism of heart injury among patients infected with SARS-CoV-2. Cardiovasc. Res. 2020, 116, I097-IIoo. [CrossRef]

30. Wang, Y.; Liu, M.; Gao, J. Enhanced receptor binding of SARS-CoV-2 through networks of hydrogen-bonding and hydrophobic interactions. Proc. Natt. Acad. Sci. USA 2020, 117, 13967-13974. [CrossRef]

31. Wrapp, D.; Wang, N.; Corbett, K.S.; Goldsmith, J.A.; Hsieh, C.-L.; Abiona, O.; Graham, B.S.; McLellan, J.S. Cryo-EM structure of the $2019-\mathrm{nCoV}$ spike in the prefusion conformation. Science 2020, 367, 1260-1263. [CrossRef]

32. Verdecchia, P.; Cavallini, C.; Spanevello, A.; Angeli, F. The pivotal link between ACE2 deficiency and SARS-CoV-2 infection. Eur. J. Intern. Med. 2020, 76, I4-20. [CrossRef] [PubMed]

33. Hoffmann, M.; Kleine-Weber, H.; Schroeder, S.; Krüger, N.; Herrler, T.; Erichsen, S.; Schiergens, T.S.; Herrler, G.; Wu, N.-H.; Nitsche, A.; et al. SARS-CoV-2 Cell Entry Depends on ACE2 and TMPRSS 2 and Is Blocked by a Clinically Proven Protease Inhibitor. Cell 2020, 181, 27I-28o.e8. [CrossRef]

34. Hou, Y.; Zhao, J.; Martin, W.; Kallianpur, A.; Chung, M.K.; Jehi, L.; Sharifi, N.; Erzurum, S.; Eng, C.; Cheng, F. New insights into genetic susceptibility of COVID-19: An ACE2 and TMPRSS2 polymorphism analysis. BMC Med. 2020, 18, 216. [CrossRef]

35. Yang, X.-H.; Deng, W.; Tong, Z.; Liu, Y.-X.; Zhang, L.-F.; Zhu, H.; Gao, H.; Huang, L.; Liu, Y.-L.; Ma, C.-M.; et al. Mice transgenic for human angiotensin-converting enzyme 2 provide a model for SARS coronavirus infection. Comp. Med. 2007, 57, 450-459.

36. Huang, F.; Guo, J.; Zou, Z.; Liu, J.; Cao, B.; Zhang, S.; Li, H.; Wang, W.; Sheng, M.; Liu, S.; et al. Angiotensin II plasma levels are linked to disease severity and predict fatal outcomes in $\mathrm{H}_{7} \mathrm{~N}_{9}$-infected patients. Nat. Commun. 2014, 5, 3595. [CrossRef]

37. Gu, H.; Xie, Z.; Li, T.; Zhang, S.; Lai, C.; Zhu, P.; Wang, K.; Han, L.; Duan, Y.; Zhao, Z.; et al. Angiotensin-converting enzyme 2 inhibits lung injury induced by respiratory syncytial virus. Sci. Rep. 2016, 6, i9840. [CrossRef]

38. Wang, X.; Ye, Y.; Gong, H.; Wu, J.; Yuan, J.; Wang, S.; Yin, P.; Ding, Z.; Kang, L.; Jiang, Q.; et al. The effects of different angiotensin II type i receptor blockers on the regulation of the ACE-AngII-ATI and ACE2-Ang(I-7)-Mas axes in pressure overload-induced cardiac remodeling in male mice. J. Mol. Cell. Cardiol. 2016, 97, I80-190. [CrossRef]

39. Ishiyama, Y.; Gallagher, P.E.; Averill, D.B.; Tallant, E.A.; Brosnihan, K.B.; Ferrario, C.M. Upregulation of Angiotensin-Converting Enzyme 2 After Myocardial Infarction by Blockade of Angiotensin II Receptors. Hypertension 2004, 43, 970-976. [CrossRef] 
40. Vaduganathan, M.; Vardeny, O.; Michel, T.; McMurray, J.J.; Pfeffer, M.A.; Solomon, S.D. Renin-Angiotensin-Aldosterone System Inhibitors in Patients with Covid-19. N. Engl. J. Med. 2020, 382, 1653-1659. [CrossRef]

4I. Shi, S.; Qin, M.; Shen, B.; Cai, Y.; Liu, T.; Yang, F.; Gong, W.; Liu, X.; Liang, J.; Zhao, Q.; et al. Association of Cardiac Injury With Mortality in Hospitalized Patients With COVID-ı9 in Wuhan, China. JAMA Cardiol. 2020, 5, 802. [CrossRef]

42. Zhou, F.; Yu, T.; Du, R.; Fan, G.; Liu, Y.; Liu, Z.; Xiang, J.; Wang, Y.; Song, B.; Gu, X.; et al. Clinical course and risk factors for mortality of adult inpatients with COVID-ı9 in Wuhan, China: A retrospective cohort study. Lancet 2020, 395, 1054-1062. [CrossRef]

43. Kassiri, Z.; Zhong, J.; Guo, D.; Basu, R.; Wang, X.; Liu, P.P.; Scholey, J.W.; Penninger, J.M.; Oudit, G.Y. Loss of Angiotensin-Converting Enzyme 2 Accelerates Maladaptive Left Ventricular Remodeling in Response to Myocardial Infarction. Circ. Heart Fail. 2009, 2, 446-455. [CrossRef]

44. Gommans, D.H.F.; Nas, J.; Pinto-Sietsma, S.-J.; Koop, Y.; Konst, R.E.; Mensink, F.; Aarts, G.W.; Konijnenberg, L.S.; Cortenbach, K.; Verhaert, D.V.; et al. Rationale and design of the PRAETORIAN-COVID trial: A double-blind, placebo-controlled randomized clinical trial with valsartan for PRevention of Acute rEspiraTORy dIstress syndrome in hospitAlized patieNts with SARS-COV-2 Infection Disease. Am. Heart J. 2020, 226, 60-68. [CrossRef] [PubMed]

45. Chen, J.; Jiang, Q.; Xia, X.; Liu, K.; Yu, Z.; Tao, W.; Gong, W.; Han, J.J. Individual variation of the SARS-CoV-2 receptor ACE2 gene expression and regulation. Aging Cell 2020, 19. [CrossRef] [PubMed]

46. Gagliardi, M.C.; Tieri, P.; Ortona, E.; Ruggieri, A. ACE2 expression and sex disparity in COVID-19. Cell Death Discov. 2020, 6, 37. [CrossRef]

47. Guan, W.-J.; Liang, W.-H.; Zhao, Y.; Liang, H.-R.; Chen, Z.-S.; Li, Y.-M.; Liu, X.-Q.; Chen, R.-C.; Tang, C.-L.; Wang, T.; et al. Comorbidity and its impact on 1590 patients with COVID-I9 in China: A nationwide analysis. Eur. Respir. J. 2020, 55, 2000547. [CrossRef]

48. Swärd, P.; Edsfeldt, A.; Reepalu, A.; Jehpsson, L.; Rosengren, B.E.; Karlsson, M.K. Age and sex differences in soluble ACE2 may give insights for COVID-19. Crit. Care 2020, 24, 221. [CrossRef]

49. Galbadage, T.; Peterson, B.M.; Awada, J.; Buck, A.S.; Ramirez, D.A.; Wilson, J.; Gunasekera, R.S. Systematic Review and Meta-Analysis of Sex-Specific COVID-r9 Clinical Outcomes. Front. Med. 2020, 7, 348. [CrossRef]

5o. Sama, I.E.; Ravera, A.; Santema, B.T.; Van Goor, H.; Ter Maaten, J.M.; Cleland, J.G.F.; Rienstra, M.; Friedrich, A.W.; Samani, N.J.; Ng, L.L.; et al. Circulating plasma concentrations of angiotensin-converting enzyme 2 in men and women with heart failure and effects of renin-angiotensin-aldosterone inhibitors. Eur. Heart J. 2020, 41, I810-I817. [CrossRef]

5I. Imai, Y.; Kuba, K.; Rao, S.; Huan, Y.; Guo, F.; Guan, B.; Yang, P.; Sarao, R.; Wada, T.; Leong-Poi, H.; et al. Angiotensin-converting enzyme 2 protects from severe acute lung failure. Nat. Cell Biol. 2005, 436, ${ }_{112-116 .}$ [CrossRef]

52. Wambier, C.G.; Goren, A.; Vaño-Galván, S.; Ramos, P.M.; Ossimetha, A.; Nau, G.; Herrera, S.; McCoy, J. Androgen sensitivity gateway to COVID-r9 disease severity. Drug Dev. Res. 2020. [CrossRef]

53. Hoffmann, M.; Schroeder, S.; Kleine-Weber, H.; Müller, M.A.; Drosten, C.; Pöhlmann, S. Nafamostat Mesylate Blocks Activation of SARS-CoV-2: New Treatment Option for COVID-19. Antimicrob. Agents Chemother. 2020, 64. [CrossRef]

54. Kai, H.; Kai, M. Interactions of coronaviruses with ACE2, angiotensin II, and RAS inhibitors-Lessons from available evidence and insights into COVID-19. Hypertens. Res. 2020, 43, 648-654. [CrossRef]

(C) 2020 Copyright by the authors. Licensed as an open access article using a CC BY 4.0 license.

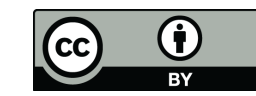

